\title{
PAUL AT ATHENS: FRESH INSIGHTS
}

\author{
William Edgar \\ Westminster Theological Seminary, USA \\ Korespondensi: wedgar@wts.edu
}

\begin{abstract}
This article discusses the challenges towards the Christian principles in adapting biblical message today. It starts with the growing trend toward individualism and privatization of religion, violence, and finally persecution. I will analyze the apologetics method in the famous speech given by the apostle Paul on Mars Hill, recorded in Acts 17:16-34. Then, finally making proposals on how Paul's approach to be used in the practice of today's Christian apologetics based on the challenges given above.
\end{abstract} KEYWORDS: Paul; privatization; faith; religion; apologetics; individualism.

ABSTRAK: Artikel ini membahas berbagai tantangan terhadap prinsip-prinsip Kristen dalam menyesuaikan pesan Alkitab pada masa kini. Ini dimulai dengan tren yang berkembang ke arah individualisme dan privatisasi agama, kekerasan dan akhirnya penganiayaan. Saya akan menganalisis metode apologetika dalam pidato terkenal yang diberikan oleh rasul Paulus di Mars Hill, yang dicatat dalam Kisah Para Rasul 17: 16-34. Kemudian, akhirnya membuat proposal tentang bagaimana pendekatan Paulus perlu digunakan dalam praktik apologetika Kristen dewasa ini berdasarkan berbagai tantangan yang diberikan di atas.

KATA KUNCI: Paulus; privatisasi; iman; agama; apologetika; individualisme.

Many people sense that the church, both in the North and the Southern Hemispheres (better now called the Majority World), is at a crossroad. There was certainly never a golden age, nor a time when the consensus so favored Christian principles that great efforts were not required to adapt the biblical message to meet the needs of the specific times. But there appear to be special challenges today. 
To list a few, we can identify (1) the growing trend toward individualism. Many have written about it. Charles Taylor may be among the most articulate. ${ }^{1}$ He argues that there has been an increasing separation between the self and the good in Western intellectual history. He laments the concomitant departure from rationality implied. We may quibble with some of the details. Surely some of the more positive aspects of the evolution of the modern self can be attributed to Martin Luther and the Protestant Reformation. Yet by our own time, the emphasis on the self has become extreme. . We want to flourish individually, we want to "follow our hearts", we want liberty and human rights to the point where identity trumps all other values.

(2) Religion has become privatized. Many have commented on this trend. Privatization is a broad concept with implications for business, law and politics. But religious privatization was born in connection with the rise of liberalism. Ironically, classic liberalism as it developed in the nineteenth century was committed to strengthening the public nature of the state, rather than shying away from it. At its best, as Stephen Holmes argues, privatization of religion could be a means toward principled pluralism and the quelling to strive between competing religions. ${ }^{3}$ Yet privatization can have its negative effect, especially for Christians. Os Guinness has taught us that it makes us free to believe whatever we want, whether it be traditional faith or any religious notions, as long as we do not seek to impose these views on others. ${ }^{4}$ In other words privatization can have the effect of gagging us rather than contributing to public life.

(3) In today's charged atmosphere, often if we do try to go public with our views, we are then accused of violence. The extreme form of this view would be someone like Richard Dawkins who compares the inculcation of faith to children with child abuse. A slightly more sophisticated for is the statement at the beginning of Charles Kimball's book, When Religion Becomes Evil, that says, "It is somewhat trite, but nevertheless sadly true, to say that more wars have been waged, more people killed, and these days more evil perpetrated in the name of religion than by any other institutional force in human history." 5 There does not follow a shred of evidence for this "trite"

\footnotetext{
1 See Charles Taylor, Sources of the Self: The Making of the Modern Identity (Cambridge: Cambridge University Press, 1989).

2 Timothy Wengert comments helpfully on the difference in "Martin Luther's Road to Freedom," The Freedom of a Christian (Minneapolis: Fortress Press, 2008), 25-26.

3 See Stephen Holmes, Benjamin Constant and the Making of Modern Liberalism (New Haven: Yale University Press, 1984), esp. 241-252.

4 Os Guinness, The Gravediger Files (Downers Grove: InterVarsity Press, 1983), 55.

5 Charles Kimball, When Religion Becomes Evil (Harper: San Francisco, 2002), 1.
} 
view. Indeed, as many have argued, the concept of religion is likely to be a recent invention, since in ancient times there really was no separation between various institutions and some abstract idea of religion. ${ }^{6}$

(4) In many places the Christian faith is severely persecuted. It has ever been thus. Here the parallels with the early church are patent. Up until 312 the Christian religion was considered illicita, which means something like "impermissible," although there had never been a legal undergirding for this intolerance. In today's China, Christians are experiencing increasing harshness on the part of the government; although well-articulated legislation is missing. The same is true in many parts of the globe: Middle Eastern Syrians, North Koreans, Afghanistan, Somalia, Libya, Pakistan, Yemen, and more. ${ }^{7}$ It is possible that one out of every nine believer risks some degree of persecution. ${ }^{8}$

Numerous other trends may be noted. In view of these developments, there is a growing consensus that recognizes Christian apologetics must either be abandoned altogether or be reconfigured. The reason is simple. The times are so confusing that what might previously have formed a point of contact, for example, conventions about the use of reason, criteria for the evaluation of proofs and evidence, is no longer universally received. The awareness of this has driven some to forego the practice of apologetics altogether. Most of us are aware of Karl Barth's arguments for avoiding apologetics: giving too much credence to unbelief, turning Christian faith into a system, etc. ${ }^{9}$ But not everyone is aware that objections to apologetics also were articulated by evangelicals. No less a light than Charles Spurgeon claimed doing apologetics was like attempting to defend a lion in his cage; far better just to let him out. ${ }^{10} \mathrm{C}$. S. Lewis himself, though he spent most of his life doing it, thought he was opposed to apologetics, calling it "spectral" and "unreal". ${ }^{11}$

The objections are plausible. A good many kinds of apologetics up until the twentieth century tacitly endorsed an Enlightenment view of

\footnotetext{
6 See William T. Cavanaugh, "Does Religion cause violence? Behind the Common Questions Lies a Morass of Unclear Thinking" Harvard Divinity Bulletin (Spring/Summer 2007, 35), 2-3.

7 Many groups monitor these persecutions. See particularly the Voice of the Martyrs [https:// www.persecution.com/flw/?_source_code=GSA20B1\&gclid=EAIaIQobChMIubyYx9-15wIVhJ6zCh14Aw8KEAAYASAAEgLI9PD_BwE].

8 Open Doors [https://www.opendoorsusa.org/christian-persecution/].

9 See his Church Dogmatics 1.2. Also, Kenneth Oakes on Barth's views on apologetics in the symposium Karl Barth On Theology and Philosophy [https://syndicate.network/symposia/theology/ karl-barth-on-theology-and-philosophy/].

10 Charles H. Spurgeon, "Christ and his Coworkers," The Metropolitan Tabernacle Pulpit Sermons, vol. 42 (London: Passmore \& Alabaster, 1896), 256. But note he wasn't altogether opposed to the defense of the faith as such [http://www.apologeticsindex.org/3030-spurgeon-defending-the-faith].

11 See [https://www.str.org/blog/cs-lewis-danger-apologetics\#.XjhHftVKj9Q].
} 
rationality, and then argue that the Christian faith, as it were, passes the test. ${ }^{12}$ The feeling by both Barth and Spurgeon, who come from rather different theological horizons, is that apologetics is a human discipline, at best a distraction from the power of the gospel, at worst a betrayal of it. And yet... The main reason we cannot simply abandon apologetics is that it is mandated in Scripture both by commandment (1 Peter 3:15) and example (Philippians 1:7, 17; Acts 19:23; 22:1).

So, our only option today is to reconfigure this discipline and attempt to apply it to our times in order to pry open our different cultures. One possible avenue is to revisit the famous speech given by the apostle Paul on Mars Hill. Known as the Areopagus address, it is recorded in Acts 17:16-34. We do not know all the details about this stopping place in his journey. Paul had just come from a most significant mission in Macedonia. It was the first time the gospel was preached in Europe. The eminent Catholic historian Christopher Dawson made the interesting comment that while the travels of an itinerant preacher from one side of the Aegean to the other would not have caught the attention of conventional historians. And yet, argues Dawson, it was a most significant event for world history. The gospel was preached in one of the great centers of civilization, one that would inform European culture for at least two millennia. Eventually Europe would be Christianized, and Rome would fall. ${ }^{13}$

This passage is subject to a number of controversies. One of them is sparked by exegetes who maintain that Paul's approach in Athens was ill-advised. He recognized that, so when he got to Corinth, he revised his approach. This view is typified by William M. Ramsay, who argues that Paul had attempted accommodation to worldly philosophies in Athens, but in view of the poor results, preached only "Christ and him crucified" in Corinth, and saw the founding of a large church there. ${ }^{14}$ This view is reinforced by noting that at the end Paul does not preach the atonement but only the judgment (vv.30-31).

While this view may have surface plausibility it falters on several levels. First, neither the author, Luke, nor Paul himself make the slightest suggestion that the Athenian approach was a mistake. Second, declaring

12 A notable exception to this is the tradition known as "presuppositionalist" or, more recently, "covenantal." This school puts into question the rationalist foundations of Enlightenment thinking. It is the one the present author embraces.

13 Christopher Dawson, Religion and the Rise of Western Culture (New York: Doubleday, 1958), 27-28.

14 William M. Ramsay, St Paul the Traveller and Roman Citizen (Grand Rapids: Kregel, 2001), 252. 
to the Corinthians he determined to know only Christ and him crucified (1 Corinthians 2:2) cannot be taken to mean he repeated the words like a mantra. Nor could it mean he returned to a direct description of the cross over and over. Indeed, the epistle contains some of the most involved theological reasoning in the New Testament. He surely means that the crucified Christ is at the center of his presentations. That center is the same in the Mars Hill discourse, since in the end, Paul declares that the judgment is presided by the risen Jesus (risen after the crucifixion).

A second, far more complex issue regards Paul's apologetic method. On the surface it appears that he endorses the insights of the Athenians to a certain degree, and then builds on them toward the Christian message. He quotes locally appreciated poets. The phrase "In him we live and move and have our being" can be found in Epimenides, a somewhat elusive figure that was brought in to Athens to reform some of its culture. "For we are indeed his offspring" is no doubt a quote from Aratus, a Macedonian poet from the Soli in Cilicia. Furthermore, he notices an altar "to the unknown god." He then tells them that what they are worshiping in ignorance, he will declare as the truth to them. Could it be that Paul is building on natural revelation and ending up in a "higher" place?

If we only had these clues from Acts 17, we might be tempted to conclude that Paul is laying a foundation from natural revelation and building up to what can only be known through special revelation. A similar analysis is often made of Psalm 19, which begins with "nature" and ends with "grace." ${ }^{15}$

So, first, we would need to corroborate this view with the rest of Paul's writings. Upon examination, though, it is clear that he teaches the exact opposite. In Romans chapter 1 he declares that God's wrath is revealed against the ungodliness that leads to all kinds of perversions. He states in Romans 3 that no one is righteous, nor does anyone even seek after God (vv. 10-11). To the Ephesians he writes that everyone is spiritually dead, and all walk-in trespasses and sins (2:1). To Timothy he writes that in these days people are lovers of self, lovers of money, proud, arrogant, etc. (2 Timothy 3:1-2). These and other teachings simply cannot square with the view that he is building upon a pagan foundation. Consider, too, in some of his earliest preaching, an absolute antithesis is articulated between the gospel and paganism. For example, he reminds the Thessalonians that they had "turned to God from idols" (1 Thessalonians 1:9). His sermon at Lystra

15 In fact, this is not the way the Psalm works. The illustration of the sun is just that, an illustration. It is meant to portray the deep penetration of God's presence. 
says the people should turn from vain things to a living God, the creator of everything (Acts 14:15).

A closer look at Acts 17 shows that while he does establish contact with the pagan philosophies of the day, he does not necessarily approve them. Paul (and others) freely quotes those who may have a surface insight, but who do not at all share the same foundation. In Titus he quotes the saying, "Cretans are always liars, evil brutes, lazy gluttons" (Titus 1:12), which seems to be from Epimenides. ${ }^{16}$ He quotes Menander in 1 Corinthians when he says "Bad company corrupts good character."17 There are possible other quotes as well. ${ }^{18}$ The apostle cannot possibly be in agreement with the worldview of these philosophers, given his own approach. Indeed, in this same speech at Athens he is sharply critical of their idols, which articulate that God is served by human hands, has needs, etc. (v 25). Instead, he declares God to be the creator of everything, and the nations, and their calling (vv. 24-27)

His statement that "what you worship as unknown, this I proclaim to you" (v. 23) also needs unpacking. The question is whether "what you worship" is the antecedent for "this". In other words, is he saying he will tell them exactly what it is they are worshiping, only perhaps more clearly so? On this view Paul is not so much building on an opposite worldview as he is recognizing the nature of general revelation. The God whom Paul proclaims made mankind out of one, and gave it the purpose of seeking God in the hopes they would find him (vv. 24-27). This is what the Athenians are doing. The fact is he is not far from us (vv. 27-28), as their own poets acknowledge.

However, it is one thing for Paul to recognize an awareness, a "sense of deity" as Calvin puts it, one which is right as far as it goes, but quite another to endorse the worldview of the poets and the altar. If you look carefully into the pagan belief system, you should see how Paul can give approval to the surface statements of the poets, without endorsing the framework out of which they come. This accords with Romans 1:18-20, where he affirms the knowledge of God, on the one hand, but the wrong way to process that knowledge, on the other. We know God; not just about him but him, in reality. But we refuse to honor him or give him thanks. This makes our knowledge culpable. Paul calls the worship by the Athenians ignorant. This

16 This quote contains a logical conundrum since Paul quotes it as from "a prophet of your own." Which would put him in the category of liars. Most exegetes point out that Epimenides (a poet) was speaking in hyperbole, and did not mean to imply that every single Cretant only told lies.

17 Menander was a Greek dramatist (c.342-c. 290), a representative of "Athenian New Comedy."

18 Some scholars believe, for example, that the saying "the good that I would I do not; but the evil which I would not, that I do" (Romans 7:19) is an adaptation from Hippolytus. 
word means much more than simply ignoring a few facts. It is the blameworthy ignorance of a willful turning away from the truth. So, it simply cannot be said that he considers the Athenians right at a foundational level, but needing a complement to go further. It is quite the other way around: they are right at a superficial level, but cannot base their knowledge on a solid foundation.

As Ned Stonehouse marvelously puts it, "Paul maintained that even pagans remained confronted with the revelation of God in nature" but he adds, "and that this contact with revelation rendered them inexcusable." He goes on to state, "Thus while maintaining the antithesis between the knowledge of God enjoyed by His redeemed children and the state of ignorance which characterized all others, Paul could allow consistently and fully for the thought that pagan men, in spite of themselves and contrary to the controlling disposition of their minds, as creatures of God confronted with the divine revelation were capable of responses which were valid so long as and to the extent that they stood in isolation from their pagan systems."19

What can we learn here for the practice of apologetics today? As was his custom, Paul went first to the synagogue, but also to the market place. If we may riff on this strategy, apologetics is not only for the "outsider" but often the household of faith needs it as well. The elder, Paul tells us elsewhere, must, among other qualities, be able to defend the faith to those who challenge it (Titus 1:9). Of course, often the challenges come from unbelievers, and they need to be answered. 1 Peter 3:15 admonishes all Christians to be ready to make a defense for the hope they have.

Readiness! Paul was ready in one sense. He was well trained, well versed in Christian principles, and had tremendous experience in setting forth the message of the gospel, particularly on his missionary journeys (the Mars Hill discourse was on his second missionary journey). However, it appears that some elements of Athenian culture struck him particularly. Acts 17:16 records that Paul's spirit "was provoked within him" when he saw the many idols around the city. The word used translated "provoked" means something like, "sharpened," or brought into focus. Surely, he was not surprised, and yet it was this realization of the prevalence of idols that incited his impassioned speech. The zeal for the Lord consumed him (Psalm 69:9; John 2:17).

19 Ned B. Stonehouse, "The Areopagus Address", Paul before the Areopagus and Other New Testament Studies (London: Tyndale Press, 1957), 29-30. Italics mine. 
That should be a great example to us. Are we provoked, or sharpened in our concerns by the surrounding paganism of our world? Or have we softened our touch? Our four characteristics above, when seen as ultimate trends, amount to idolatry. Idolatry is one of the most useful concepts for understanding unbelief, in any age. Idols can be crude. We may think of idols as statues and incense, which they still are for many people. My wife and I visited a temple in Taipei which was a grand synthesis of pagan ideas. There were large statues in some sort of military garb. People were bringing incense sticks and vegetables to be burned before the formidable figures. One of the guides came over to us and explained, in very good English, that she had tried praying to the Christian God, but found no answers. Then she turned to the statues in the temple and things started coming together.

Idols work, to some extent. It is interesting to note that just before this encounter at Athens Paul and Silas went to a place of prayer in Philippi and were met by a slave girl who was possessed by "a spirit of divination" (Acts 16:16). Through this spirit she brought considerable gain to her sponsors. The spirit seemed to know that Paul and Silas served "the Most High God" (v. 17) Paul became annoyed and cast the demon out, costing them a stay in the local prison.

The Roman Empire was full of such pagan practices. Many historians, including C. S. Lewis, make a contrast between paganism and the post-Christian era. When told that paganism was having a comeback, Lewis proclaimed it good news! ${ }^{20}$ Of course he did not mean paganism was good. But he thought it was at least closer to the gospel than secularization.

There is a less crude form of idolatry as well. The world Paul entered in Greece was pagan, though not simply the most basic kind, with statues and objects. While most of the group paid some homage to the pagan objects, some were philosophers and presumably others were educated Jewish people. The audience for the speech was a mix. Luke (the author of Acts) mentions the Jews and devout persons Paul met in the synagogue. No doubt some of them were also present in the marketplace. He also specifically mentions Epicureans, and Stoic philosophers, Athenians as well as foreigners. The Epicureans were disciples of Epicurus, whose school was founded around $307 \mathrm{BC}{ }^{21}$ This view was materialistic and generally opposed to superstition. However, they did believe in the gods, who nevertheless were not involved in earthly matters. Their central stress was on living for pleasure

20 C. S. Lewis, "Is Theism Important?" in God in the Dock, ed. Walter Hooper (Grand Rapids: Eerdmans, 1970), 172.

21 See Catharine Wilson, Epicureanism: A Very Short Introduction (New York: Oxford University Press, 2015). 
(hence our expression about a bon-vivant, "he lives like an Epicurean.") Such pleasure was meant to be cerebral and not sensual, though eating good food was acceptable. They rejected any notion of immortality. Paul's message would have stirred them up, since he did preach the God who made the world and who gives life and breath and everything to mankind (vv. 24-25).

The other classical philosophers present were the Stoics. This view was founded by Zeno of Citium (Cyprus) in about 300 BC. ${ }^{22}$ Founded in the Stoa, or Porch (Stoa Poikile, or "painted porch," an open market in Athens where the original Stoics taught publically). It thus flourished in Athens. Under later versions, such as Roman Stoicism, it wielded considerable influence. Marcus Aurelius was an enthusiastic adherent. It centered on the practice of virtue, aided by logic and natural science. When successful it should lead to Eudaimonia, or happiness. This view stressed self-control, the banishing of destructive emotions, and conformity to the course of the universe. In popular parlance, a Stoic can face life's issues with levelheadedness. Again, Paul's message would have confronted the Stoic's claim of self-sufficiency.

It would be a truism to say this was a cosmopolitan city. Though perhaps no longer in its heyday, it was still a center of thought and of the exchange of ideas. From Paul's voyages, and his pausing in various cities, it may be fairly argued that urban ministry is strategic in any age. This is not to disparage the countryside. In fact, the one cannot exist without the other. Although the countryside is losing its population, cities cannot survive without what they bring. ${ }^{23}$

The reception by this mixed group is fascinating. The classical philosophers "conversed with him" (v. 18). How we would love to have been a fly on the wall to witness those discussions! Paul was well versed in these views, and so he presumably engaged the adherents on their own level. Today, there are approaches to apologetics that espouse competency in philosophy. One may think of the popularizer Francis A. Schaeffer, who had a grasp of philosophies of the day, such as Existentialism, Heidegger, Jaspers, Huxley, etc. At a more scholarly level, we may think of Reformed epistemologist Alvin Plantinga, and his defense of the goodness of God in the face of evil. Theologians such as Timothy Keller have thoroughly grasped, and interacted with, Canadian philosopher Charles Taylor, whose understanding of the rise of individualism has redirected the history of ideas. ${ }^{24}$

22 See Donald Robertson, Stoicism and the Art of Happiness (London: John Murray Press, 2018).

23 See Wharton University Public Policy [https://publicpolicy.wharton.upenn.edu/live/news/2393 -rural-america-is-losing-young-people-]

24 See Timothy Keller, Preaching; Communicating Faith in an Age of Skepticism (New York: Viking, 2015), 121-156. 
As was the case in Athens, not everyone is a highly educated philosophical thinker. Luke wryly comments that both the Athenians and the foreigners spent their time "in nothing except telling or hearing something new" (v. 21). Does this sound familiar? Our news media celebrate a constant flow of "breaking news." Advertisers know that if you put the adjective new in front of a product it gets the attention of the consumer. Even in theology, we are treated to "the new hermeneutic," and "the new perspective on Paul." I have often thought this kind of audience would make it very hard to preach something new, but also timeless. In Athens they called him a babbler, a preacher of foreign divinities, and the bringer of strange things to their ears (vv. 18-20).

A few applications would seem in order. First, and most basic, just as it was in the First Century, so it is now, apologetics is sorely needed. Athens represented one of the most influential centers for the generation of ideas. As the classicist historian Humphrey Kito once put it, The Athenians were "not very numerous, not very powerful, not very organized... yet they had a totally new conception of what human life was for, and showed for the first time what the human mind was for." ${ }^{25}$ One might plausibly argue that this view ignores the role of the Hebrew culture, whose idea of the purpose of mankind dates back to the creation order (Genesis 1:26-31). But Athens was a world-class city which successfully exported its best ideas all over the ancient world..$^{26}$ This is surely one of the reasons Paul stopped there, and one of the reasons Luke elaborates on his speech more than others.

Christian apologetics should not concentrate exclusively on worldclass cities, but it should make every attempt to understand their culture and influence. In the United States one thinks of New York, Washington DC, Los Angeles and even Silicone Valley. In China, Shanghai, Beijing, and Hong Kong. In Southeast Asia, Jakarta, Indonesia, Kuala Lumpur. And several other places. Of course, there is Seoul, Korea, Tokyo, Japan, Sydney, Australia, and perhaps Moscow, Russia. In Europe one can think of numerous places: London, Paris, Rome, Berlin, Amsterdam. In Africa, Nairobi and Cape Town.

Second, Paul's approach should be considered a model for our apologetics in this generation. Let us rapidly look at the four traits above and

\footnotetext{
25 SGW Books, The Atlantic, February 10, 2016. [https://www.theatlantic.com/science/archive/2016/02/ what-made-ancient-athens-a-city-of-genius/462009/].

26 See Eric Weiner, The Geography of Genius: Lessons from the World's Most Creative Places (New York: Simon \& Schuster, 2016), 13-64.
} 
apply Paul's approach to them. (1) Individualism. Here I think we might look for evidence that modern people rightly recognize the need for proper individuality but then go off the deep end by denying the foundations for it. Acknowledging the high place of the individual is a profoundly biblical notion. If Paul could appeal to the creation account, so must we. (Acts 17:2428). In the case of the importance of the individual we can appeal to the creation of mankind after God's own image. Martin Luther is often credited with discovering the place of the individual before God but of course this idea goes back much further.

And the effects of this understanding are still with us. And not all is negative. As Charles Taylor argues, part of the modern turn toward the self is the result of a personal longing to reach the good. ${ }^{27}$ We have learned that ethics is far more than slavishly following a set of rules, but must involve motive. Even the more Enlightenment oriented philosophers such as John Locke are influenced by the Judeo-Christian notion of the need for moral uprightness to be more than external.

On the other side of this issue is individualism. Here, the turn to the self is unhealthy. Again, Charles Taylor describes this as a romantic turn, and blames those who have taken Jean-Jacques Rousseau's views to an extreme. Rousseau's philosophy has led to the notion that, "We now can know from within us, from the impulses of our own being, what nature marks as significant." ${ }^{28}$ In the $21^{\text {st }}$ century looking to the self has become epidemic. Lawrence Samuel has written that "now individualism-acting in one's own interests versus those of an organized group or governmentis arguably the guiding principle of our times." ${ }^{29}$ There are thousands of illustrations. One pundit calls ours the "selfie culture."

So, following Paul's example, we should denounce this rampant form of individualism as an idol. Cornelius Van Til, the celebrated apologist, has named the central conflict in human history as one of the location of authority. He often compared biblical authority to the authority of the expert. He says, "The natural man will gladly allow for the idea of authority if only it is the authority of the expert in the use of reason." ${ }^{\prime 30}$ Again, the apostle Paul appeals to the authority of God's judgment (Acts. 17:30-31).

Our second theme is the privatization of religion. Again, there are positive aspects of this. We cannot in this space go into the details of

27 Charles Taylor, Sources of the Self, 25-52

28 Ibid, 362.

29 [https://www.psychologytoday.com/us/blog/future-trends/201808/the-rise-me-cul ture]

30 Cornelius Van Til, Christian Apologetics, Second Edition, ed., William Edgar (Phillipsburg: P \& R Publishing, 2003), 162. 
secularization theory. But here it is useful to remember that originally the secularization of society meant that the church could not wield its power on sectors where it should have no administrative connections. This should be seen as an advantage for the purposes of Christian outreach. Abraham Kuyper commented on this good aspect to secularization. Or, put another way, he was strongly in favor of the disestablishment of the church, which he did not think would lead to an atheistic society but quite the contrary. His Anti-Revolutionary Party was not to be confused with ecclesiastical power. ${ }^{31}$

Furthermore, secularization is quite a mixed bag. Most, though not all, advocates of the standard model of secularization have abandoned many parts of it. That model said that as mankind matured, religion would no longer be needed, and he could live by the light of reason. The facts showed otherwise: religion is alive and well, although to be sure, in some places church attendance is down, and the influence of the Christian faith on the surrounding culture is diminished. ${ }^{32}$ Here, of course, there are all kinds of parallels with the world into which Paul spoke the gospel. Religion was omnipresent in Athenian culture, even though it may only have had a token influence.

There are some today who proclaim that Christians should retreat from social involvement. If I have understood him correctly, Rod Dreher is telling us we should retreat in monastery-like places, having lost the culture wars, but being in need of safe havens where we can regroup and be better discipled by the Lord. ${ }^{33}$ Dreher argues that the retreat into "Christian villages" must not be done out of fear, but out of love. One of his favorite images is Noah's Ark, the famous ship that protected one family from the flood. But there are at least two related issues here that are misguided, in my judgment. The first is that Dreher invests too much in the church, or in church-like bodies. This is a call to go back to a time when the church was the greatest cultural influencer. To be sure, Dreher's "church" is not the medieval church, with its popes and bishops. Coming from the Anabaptist tradition, his community is rather a spiritual entity, low on structure, high on fellowship.

The second problem is itself twofold. At the least it stems from a naïve view of culture wars. The culture war model, with its white hats and black hats, portrays a winner-takes-all view of social involvement. But the Bible

31 James D. Bratt, Abraham Kuyper: Modern Calvinist, Christian Democrat (Grand Rapids: Eerdmans, 2013), 137.

32 See James V. Spickard, "Narrative Versus Theory in the Sociology of Religion" in eds. James A. Beckford \& John Walliss, Theorizing Religion (New York: Routledge, 2017), chapter 12.

33 Rod Dreher, The Benedictine Option: A Strategy for Christians in a Post-Christian Nation (New York: Penguin - Random house, 2017). 
looks at our daily battles as multiple fronts, family, state, trade, law, the arts, these all require wise submission to the Lordship of Christ as appropriate to each sphere. To be sure, the underlying dynamic of these skirmishes is the great warfare between the seed of the woman and seed of the serpent (Genesis 3:15; Revelation 12). But we no more measure the victories and defeats in the visible world than we can know where we are in this larger scheme. The images of salt and light are more indicative of our approach than the culture war model. Second, retreating from the world, no matter how one dresses it up as an Ark or a boot-camp, risks lack of love for the place where God has put us. I am certain that is far from Dreher's intentions, but that could be the result.

We should indeed preach the falsity of "religion" if that means statues and altars, or even ideologies. At the same time we need vigorously to proclaim the unique Lordship of Christ as the one who is truly to be reckoned with. He it is who holds the keys of death and Hades, the only enemies that really matter (Revelation 1:18). Even though now we do not fully see his lordship over all things (Hebrews 2:8) yet the day is coming when the world will be judged publically. Drawing on Noah's story, the apostle Peter warns that justice delayed is not justice denied. The Lord did not spare the ancient world, and so why should he spare ours, if we don't turn to the gospel.

The third general trend mentioned above describes the hostility of people against those who believe the gospel. Again, we do not have time to delve fully into the debate, whether religion causes violence. David Martin has laid this accusation to rest in his remarkable book, Does Christianity Cause War? ${ }^{34}$ His basic argument is that neither human nature as such, nor religion as such cause violent conflict. Instead, wars are caused by a blurring of the lines between nationalistic principles, and the religious culture which often characterizes them. He has eloquent arguments from the Gospels to the effect that Christ calls us to be peace-makers.

Timothy Keller, again, following a host of thinkers, reminds us that often those who accuse Christians of coercion are rather coercive themselves. In his ground-breaking book, The Reason for God, he takes on a number of typical objections to the Christian faith. One of them is that to claim a particular faith is exclusive is arrogant and coercive. While showing some sympathy for this view, Keller then shows how those who hold this particular view are no less free from arrogance than those whom they accuse. And he supplies evidence from totalitarian states who thought the eradication of

34 (New York: Oxford University Press, 1998) 
all religion would free mankind to progress, when in fact they accomplished just the opposite..$^{35}$

In her own creative way Rebecca McLaughlin answers the question, whether religion causes violence. ${ }^{36}$ Like Keller, she shows some sympathy with the view that attaches violence to religion. She then proceeds to debunk most of the standard accusations: the crusades, Buddhism, communism, the Nazis, etc. In each case she shows how inside the velvet glove of an attack on the Christian faith is an iron fist thinly disguised. She also reminds us of all the good done because of the Christian faith: hospitals, schools, peace treaties, and so forth. Her arguments surrounding the Nazi persecutions are particularly compelling, making it hard not to see analogies to our own times.

While Paul's speech does not directly confront the issue of human violence, it is there in the subtext. First, in his kindness in accepting the invitation to speak "strange things" to their ears, he is demonstrating his conviction that this audience is full of human beings. While it may have been tempting to demonize them, instead he patiently and respectfully interacts with their views and their culture. He "reasoned" in the synagogue (v. 17) ${ }^{37}$ One of the major themes of his message is that everyone is the same. All humanity is made from one person. We are all God's offspring. Though spread all over the earth, our purpose is not to go to war, but to seek after God from within the allotted boundaries. And we will be judged by a man, the God-man Jesus Christ, one of us!

It is my conviction that one of the teachings from the gospel most needed in our time is the image of God. No other doctrine is quite so revolutionary. It was thus when taught by Moses. The Genesis account is, among other things, a polemic against local religions. The Babylonians, for example, believed that the creation of mankind was in order to relieve the gods of their burdens. The biblical witness, however, make Man an image-bearer of its Creator. Quite extraordinary! Not only does this anthropology help in the battle for life, but also in the place of discourse. My opponent may be an enemy, but I must respect him as having equal rights and privileges as I. This may be unverifiable, but Voltaire is purported to have said to an adversary: "I disagree with you but will defend to the death your right to say it."

35 Timothy Keller, The Reason for God: Belief in an Age of Skepticism (New York: Dutton, 2008), 3-18.

36 Rebecca McLaughlin, Confronting Christianity: 12 Hard Questions for the World's Largest Religion (Wheaton: Crossway, 2019), 75-94.

37 We had said above that Paul was provoked in his spirit. This is true, but not incompatible with a certain compassion demonstrated throughout the speech. 
Finally, persecution. Again, while not addressing that particular issue directly, both the message and the surrounding context show the precariousness of being a believer, and how to deal with it. Paul had recently come from jail. He had been severely persecuted by the Jews, At Athens he was called a "babbler" (this is particularly insulting to a learned rabbi - Acts 17:18). He was mocked for his views (v. 32). In Corinth he was attacked again. His answer though was not revenge but persuasion (18:4). As we know persecution in the early church was sometimes very heavy indeed. It came in waves throughout the first few centuries. And as we said above, it has never been so intense as today.

What gives us courage to speak out in the face of persecution? In Paul's case that was clear. He had met the Lord Jesus whom he had been harassing and became persuaded that the Christian understanding of his religion was true. Then he went on boldly to proclaim the gospel often in the hostile environment of those who not only did not agree but found him to be some kind of traitor. What gave him such courage? There are hundreds of answers to this in the Bible. One of them is the matter of conviction. In the extraordinary passage on the ministry, he told the Corinthians, "we [also] believe and so we also speak" (2 Corinthians 4:13). He goes on to explain that the one who raised up Jesus from the dead will also raise us up, and so the great message is spread (vv. 14-15). Though in slightly different words, this is how he concludes his Mars Hill discourse. While God has been patient, now his patience is running out and it is time to turn to God, to repent, in light of the certainty of judgment, infallibly proved by the resurrection (Acts 17:30-31).

One of my heroes is Polycarp (AD 65-155). He was given a chance at age 86 to survive persecution by the simple act of burning a torch to Caesar. He would not do it, stating with these moving words, "Eighty and six years I have served [Jesus], and he has done me no wrong... How then can I blaspheme my King and Savior?" The list of martyrs in Hebrews 11 ends by saying, "though commended through their faith, [all these] did not receive what was promised, since God had provided something better for us, that apart from us they should not be made perfect" (Hebrews 11:39-40).

Well, we are in this extraordinary train of martyrs who should, like Polycarp consider it a great honor to suffer for Christ's sake. When we proclaim this immortal message with great courage, what will be the response? Mockery? The cry for an encore? Or following Christ? That is not our call. Our call is to preach the gospel, in season and out of season (2 Timothy 4:2). We have no better model for that than Paul's Areopagus address. 